\title{
Do Ownership structures affect Risk Disclosure in Islamic Banks?
}

\section{International Evidence}

\author{
Nejia Moumen \\ Tunis Business School, University of Tunis \\ LIGUE-ISCAE, University of Manouba, Tunisia \\ nejia.moumen@tbs.rnu.tn \\ Rihab Grassa \\ LIGUE-ISCAE, University of Manouba-Tunisia \\ Higher Colleges of Technology- UAE \\ rihab_grassa@hotmail.fr \\ Khaled Hussainey \\ Portsmouth Business School, Portsmouth University, \\ United Kingdom \\ khaled.hussainey@port.ac.uk
}

\begin{abstract}
:
This paper assesses the effects of deposits structure and ownership concentration on risk disclosure in Islamic banks. We based on a sample of 71 Islamic banks operating in 12 countries and observed over the period 2009-2014. We employed a risk disclosure index covering 9 dimensions. Our paper finding suggests that the level of risk disclosure is lower for Islamic banks with higher ownership concentration, leveraged bank, listed banks and Islamic banks. However risk disclosure is higher for Islamic banks with higher concentration of PSIA and higher foreign ownership, large Islamic banks, aged banks, Islamic banks operating in country with higher country transparency index, positively correlated to GDP and AAOIFI adoption. By disaggregating total risk disclosure into the 9 sub-categories, we are able to specify, also, the components of risk disclosure impacted by various determinants. Our findings suggest many policy implications. First, regulators have to
\end{abstract}


improve corporate governance mechanisms in Islamic banking system through the optimization of ownership structure (dispersed ownership) in order to promote transparency and disclosure. Second, regulators and policy makers should revise guidelines in the main purpose to protect PSIAs holders (considered as minor shareholders without voting power) through promoting disclosure and transparency. Third, our findings can be useful for many international supervisory bodies like the IFSB and AAOIFI to evaluate transparency and disclosure standards.

\section{Keywords:}

Risk disclosure, Islamic banks, block holders, foreign ownership, government ownership, PSIA, AAOIFI 


\section{Introduction}

The importance of the risk disclosure was stressed for the first time in 1998 by the Institute of Charted Accountants in England and Wales, when the institute published a discussion paper entitled "Financial Reporting of Risk-Proposals for a statement of Business Risk". The discussion paper suggested for the first time that firms have to disclose risk management information in their annual reports.

Later on, the risk disclosure in the annual reports has attracted the interest of many researchers and practitioners (e.g. Barakat \& Hussainey, 2013; Oliveira et al., 2011; Abdallah et al, 2015, AlHadi et al., 2016; Al-Hadi et al, 2017; Amran et al., 2009; Neifar \& Jarboui, 2017; Ntim et al, 2013; Nobanee \& Ellili, 2017). Previous studies provide evidences that risk disclosure, is associated, to the improvement of the corporate risk management (ICAEW, 2002), the reduction of the information asymmetry (Linsmeir et al., 2002), the minimization of the agency costs (Uddin \& Hassan, 2011), the protection of the investors (Linsley \& Shrives, 2006) and the enhancement of the company's reputation (Yang, 2007).

However, previous works assessing the determinants of banks' risk disclosure in emerging economies have many limitations. First, most of these studies focused on one aspect of risk reporting such as market risk disclosure (Al-Hadi et al., 2016; Al-Hadi et al, 2017), or operational risk disclosure (Neifar \& Jarboui, 2017) while banks' transparency about other major risk types (e.g. capital adequacy, liquidity risk..) is important for both market discipline and for their financial stability. Second, these papers focused on either financial institution at an aggregate level or on Islamic banks within only the six Gulf Cooperation Council countries (GCC) which show a relatively homogenous context and similar pattern regarding the compliance with risk related regulations. 
Our paper makes therefore an important contribution to the governance and disclosure literature by assessing the risk disclosure practices of 71 Islamic banks operating in 12 emerging economies including Bahrain, Indonesia, Jordan, Kuwait, Malaysia, Pakistan, Qatar, Saudi Arabia, Tunisia, Egypt, Turkey and UAE over a period of six years (from 2009 to 2014). First, we investigate the relatively few explored risk disclosure determinants for Islamic banking firms. Second, we focus 12 booming economies. Third, we contribute to disclosure studies by being the first study to examine the risk disclosure determinants for relatively a large sample of Islamic banks operating worldwide.

As regards the practical implications of our research, we try in this paper to assess the level of risk disclosure in Islamic banks and we identify how ownership concentration and deposits structure can influence risk disclosure. This seems to be useful for both preparers and users of annual reports, for regulators and policy makers. Also, this paper encourages regulators to improve, through the optimization of ownership structure (dispersed ownership), the Islamic banking system's corporate governance mechanisms in order to promote transparency and disclosure. In addition, this paper's findings encourage regulators and policy makers to revise guidelines with the main purpose of protecting Profit Sharing Investment Account holders (PSIA: considered to be minor shareholders without voting power) through promoting disclosure and transparency. Moreover, our findings can be useful for many international supervisory bodies, like the Islamic Financial Services Board (IFSB) and the Accounting and Auditing Organization for Islamic Financial Institutions (AAOIFI), in evaluating transparency and disclosure standards.

This paper is organized as follows: The first section reviews the relevant prior studies and develops testable hypotheses. The next section describes sample selection, data sources and variables' 
definition. The third section highlights the research methodology. The fourth section discusses the results. The fifth section provides additional tests and the final section concludes the paper.

\section{Literature review and hypotheses development}

Two theoretical approaches have been proposed to justify risk disclosure practices by non-finance and finance companies. An economic theory approach; and a social and political theory approach. While the former relies on self-interest and profit maximization of corporate management (e.g. agency theory, political costs theory, signaling theory, and proprietary costs theory), the latter focuses on the political and social relationships linking companies to stakeholders in the society (e.g. resources-based perspectives and legitimacy theory). Oliveira et al (2013) suggest that the use of multi-theoretical approaches seems likely to be fertile and to produce insights beyond those revealed in the recent risk disclosure literature. So far, our cross-countries study is grounded on agency theory, political costs theory, resources-based perspectives and legitimacy theory to explore the determinants of risk reporting in the banking sector. In the following paragraphs, we briefly explain the definitions and unique aspects of these theories and how they may apply to the banking industry.

Agency theory suggests that the information asymmetry between the agent (shareholders) and the principal (managers) can be reduced through the implementation of monitoring mechanisms likely to promote higher level of information disclosure (Jensen \& Meckling, 1976). Because investors do not play an active role in corporate management and managers tend to serve their own interests (rather than maximizing shareholders' value), information about risk would reduce investors' uncertainties. Banks are in essence risk- taking enterprises, and therefore, as a part of good risk management system, they are expected to insure an appropriate flow of risk reporting to the marketplace (Linsley \& Shrives, 2006). Such system would help monitor the attitudes of managers 
towards risk exposure, foster banks' transparency and decrease the information gap between both sides (Jensen \& Meckling, 1976; Linsley \& Shrives, 2003; Oliveira et al, 2013).

The political costs theory states that some companies may be subject to deep scrutiny from politics, public and media (Watts \& Zimmerman, 1978). In such a situation, politically visible firms will make accounting choices to counter unwanted attention and avoid costs associated with regulatory interventions (Watts \& Zimmerman, 1986). According to Healy \& Palepu (2001), earlier research sustains the view that information disclosure choices can be associated with political costs' consideration.

Companies will manage to overcome such pressure or attention, by disclosing additional information so as to manipulate their image positively and to distract attention (Birt et al., 2006; Deegan \& Gordon 1996). This argument could be particularly applied to interpret banks' risk disclosure practice. Financial institutions operate in highly regulated and visible industry. Such regulations may include, for example, minimum capital requirements for banks and financial performance constraints for insurance firms. Risk disclosure could be an effective tool to influence public opinion about banks' risk profile, signal their compliance with Basel II requirements and to restore their reputations and credibility after the occurrence of global financial crisis.

Legitimacy theory (Dowling \& Pfeffer, 1975; Kaplan \& Ruland, 1991; Lindblom, 1994; Suchman, 1995; Deegan, 2002; Magness, 2006) explains that an organization has no right to exist unless it adheres to the system of values of one society within which the organization operates. To meet these social expectations, an organization would alter its activities and comply with outsiders 'values as a part of its legitimation process (Linsley \& Kajüter, 2008; Hassan, 2008). According to this theory, banks might knuckle under institutional pressures (such as adherence to Basel II requirements) to gain enhanced social support from stakeholders; and improved legitimacy, 
resources, and survival capabilities (Carpenter \& Feroz, 2001; Ferna'ndez-Alles \& Valle-Cabrera, 2006). Banks might also exhibit their compliance and conform to any minimum risk disclosure requirements to enhance their reputations and widen their customer basis. Chen \& Roberts (2010) argue however that, despite its importance, legitimacy theory has abstract underpinnings which can be further operationalized using resource dependence theory.

The resource dependence theory is built upon a few clear-cut principles. First, an organization needs important resources to survive, grow and pursue its strategies. Second, an organization should compete to obtain and control these resources from its outside environment and from rivals. Third, power (Organizations possessing necessary resources) and its inverse, dependence (organizations depending on others for resources), play key roles in understanding interorganizational relationships (Pfeffer, 1972; Pfeffer \& Salancik, 1978, 2003; Malatesta \& Smith, 2014). Such resources can be in the form of experienced labor, financial funds, loyal customers, and reputation. According to this theory, banks might rely on risk disclosures as an effective tool to raise capital at a cheaper cost of capital from the market while minimizing political costs through improved corporate image and reputation (Pfeffer \& Salancik, 1978; Branco \& Rodrigues, 2006; Oliveira et al., 2011; Pirson \& Turnbull, 2011).

\subsection{Ownership structure and risk disclosures}

We refer to several firm-specific characteristics that were discussed in recent corporate disclosure literature to explore the determinants of risk reporting.

\section{- Blok holders and risk disclosure}


Large outside shareholders play a critical role in corporate governance, because their sizable stakes give them incentives to bear the cost of monitoring the integrity and the efficiency of firms' management (Barakat \& Hussainey, 2013). Large shareholders exert governance through two basic mechanisms. First, they can directly intervene within a firm and voice for a strategic change either via a public shareholder proposal, a private letter to management, or through voting against directors. Second, they can use share trading strategy and push down stock prices, punishing then managers for their misbehavior. The threat of both intervention and exit mechanisms induces manager to maximize shareholders' value (Edmans, 2014).

In the banking sector, Barakat \& Hussainey (2013) argue that block owners have the power to influence strategic decisions towards risk management and disclosure because of their strong voting rights. For instance, if managers fail to effectively perform their fiduciary duties, major shareholders might activate their influential voting rights and remove the underperforming executive. Oliveira et al. (2011) suggest however that in banks with major shareholders, agency costs are lower as owners tend to appropriate the benefits of monitoring management. This is likely to reduce managers' opportunistic behavior and accordingly the level of risk related information. Ntim et al., (2013) contend further, that management of firms with large shareholders may not take on disclosure practices because the costs of risk related information i.e., cost of competition, cost of litigation, and cost of regulation are most probably greater than its possible benefit i.e., information symmetry.

Surprisingly, empirical research investigating the relationship between block ownership and corporate risk disclosure are scarce, with those by Lopes \& Rodrigues (2007), Oliveira et al. (2011) and Ntim et al., (2013) being notable exceptions. These studies find that block ownership has a negative effect on risk disclosure. Thus, our first two hypotheses are stated as follows: 
H1. There is a negative association between block ownership and the extent of Islamic bank risk disclosure.

H2. There is a negative association between highest shareholder ownership and the extent of Islamic bank risk disclosure.

\section{- Foreign ownership and risk disclosure}

It is widely held that foreign investors are more sophisticated than local investors due to their quality and advanced knowledge about trading and financial market regulations. Choi, Lam, Sami, \& Zhou, (2012) contend that an increase in foreign ownership leads to a rise in shareholder activism and to an improvement in board composition. In this case, local firms are subject to greater monitoring system and more refined valuation methods. Nonetheless, foreign investors are at an information disadvantage compared with domestic investors (Choe et al., 2005). Indeed, Huafang \& Jiango (2007) argue that due to space and language barriers, foreign shareholders suffer from a higher level of information asymmetry. If so, foreign investors would associate themselves with firms offering a rich information environment (Jiang \& Kim, 2004). On these terms, pressure mounts to the directors to enhance corporate transparency and provide high quality accounting information including risk related disclosure (Sami \& Zhou, 2004; Mohobbot, 2005). It follows that information asymmetry should decline with an increase in foreign ownership while there is an increase in general transparency in the market.

Empirical finding on the association between corporate disclosure and foreign ownership are mixed. While Haniffa \& Cooke (2002) and Barako et al. (2006) showed that higher level of foreign ownership increases corporate disclosure, Mohobbot (2005) and Mousa \& Elamir (2014) found 
insignificant association between risk related information and foreign ownership. Hence, we state the following hypothesis:

H3. There is a significant positive association between foreign investors and the extent of Islamic bank risk disclosure.

- Government ownership and risk disclosure

Only few studies discussed the effect of government ownership on corporate disclosure. Sepasi et al. (2016) provide evidence that government influence firm's disclosure. Indeed, firms can increase the expectations of state investors that are one of the most important beneficiaries in Iranian firms through increasing their disclosure quality. Al Janadi et al. (2016) show that government ownership has a moderating negative effect on the association between corporate governance factors and voluntary disclosure, which indicates that government ownership plays a negative role in the effectiveness of corporate governance. Eng \& Mak (2003) argue that significant government ownership is associated with increased disclosure. Government ownership increases moral hazard and agency problems, and disclosure is a means of mitigating these problems.

Based on these arguments, we set our fourth hypothesis as follows:

H4. There is a significant positive association between government ownership and the extent of Islamic bank risk disclosure.

- Deposit structure and risk disclosure

As all form of interest-based deposits are forbidden by Shariah law, while at the same time, trade and Profit-Loss-Sharing (PLS) arrangements are permitted; Islamic banks mobilize funds from depositors in the form of profit-sharing investment accounts (PSIA). PSIA constitute the main 
source of funding for Islamic banks. PSIAs are involved directly in the Islamic banks' medium and long term financed assets. On average, PSIA count around 62 percent of Islamic banks' assets in 12 countries in the Middle East and South East Asia (Archer \& Karim, 2009). Despite all of this, investment account holder don't have a specific privilege. Unlike shareholders, they receive no specific privileges, no warranties or voting rights that protect them from the moral hazard problem (Archer and Karim, 2009).

Previous researches demonstrates how mobilizing funds through profit-loss-sharing arrangements raise a moral hazard problem. Indeed, many studies discussed the potential conflicts of interest existing between equity holders and PSIAs holders (Archer \& Karim, 2009; Hamza \& Saadaoui 2013; Grassa 2018). PSIAs encourage Islamic banks' managers to take more risky decisions and to operate with less capital (Visser, 2009). In a highly information asymmetry context, any increase of PSIAs funds is likely to be an incentive for managers to opt for riskier investment decisions and to increase leverage since the Islamic bank runs no risk and the probability of default is supported fully by the investment account holders.

Hence, one of the key issues related to investment account holders is their powerlessness to mentor the bank's decisions in certain types of risky investment activities. Which can be an incentive for the decision makers to opt for risky decisions, henceforth, a creation of a possible conflicts of interest with respect to the potential deviation of appetite of risk between the holders of PSIAs and shareholders (El-Hawary, Grais \& Iqbal 2004).

Another issue, relating to the PSIAs, is most Islamic banks' practices to smooth profits over time which acts as a mean for hedging against unexpected future low income distributions (Archer, Karim \& Sundararajan, 2010). Such practices obstruct the transparency and reliability of disclosed 
information in the financial statements and severely constrain the users of financial statement from evaluating the Islamic bank's actual position (Abdel Karim, 2001).

Very few researches studied the relation between disclosure and PSIAs concentration. Using a qualitative research methodology applied to a sample of 12 Islamic financial institutions from Kuwait, Bahrain, UAE and Malaysia, Magalhães \& Al-Saad's (2013) findings demonstrate that the majority of Islamic banks believe that the quarterly audited financial reports with detailed explanations of each item are sufficient information for PSIAs holders. However, this study's findings are limited due to the small size of the sample used. Grassa, Husseiney \& Chakroun (2018) provide evidence that PSIAs have a positive impact on products and services disclosure. Grassa (2018) demonstrate that PSIA affect positively corporate governance disclosure. Grassa, al Halabi and Husseiney (2019) show that PSIAs increase multi-corporate disclosure (Sharia disclosure, CSR disclosure and financial disclosure).

Islamic banks, as equity-based capital structures dominated by shareholders equity and investment account holders, are exposed greatly to the massive risk of withdrawal of funds which threatens their positions. Therefore, we expect that since increased disclosures might maintain the investment account holders, a positive association would be predicted between PSIAs and risk disclosure.

Based on these arguments, we set our fifth hypothesis as follows:

H5. There is a significant positive association between PSIA and the extent of Islamic bank risk disclosure. 


\section{Sample, data and methodology}

\subsection{Sample and data}

Our dataset is a cross-sectional analysis of the relationship between risk disclosure, deposit structure, firm attributes and ownership structure over the period 2009-2014. We use Bankscope and the Bankers databases for the sample selection. The Bankers magazine published a survey in November 2011 of the top Islamic financial institutions by country. For the sake of consistency in our sample, we include banks which provide only financial statements. In addition, we excluded subsidiaries from our samples. Therefore, we collect data for 71 Islamic banks from 12 countries

namely Bahrain, Indonesia, Jordan, Kuwait, Malaysia, Pakistan, Qatar, Saudi Arabia, Tunisia, Egypt, Turkey and United Arab Emirates (UAE). The dataset is hand collected from several sources including Bankscope, and Zawya database, in addition to the annual reports and websites.

\section{a. dependent variable:}

To assess the level of risk disclosure across the studied countries, we use a content analysis. Krippendorff (1980) trusts that content analysis guarantees repeatability and valid inferences from data according to their contexts.

We collect data from annual reports which cover different aspects of banks' financial and nonfinancial performances. Typically, annual reports provide a review of banks' activities, their position, their risk and capital resources' management and their business vision for the future. We perform the risk disclosures' analysis of the sample banks in all the narrative sections in the annual reports. While the traditional reporting model emphasized backward-looking and quantified 
information, qualitative and forward-looking information increases the overall quality of corporate reporting and have considerable value for banks' stakeholders (Chatterjee, Tooley, Fatseas, \& Brown, 2011). Narrative sections serve as a tool for managers to disclose "their perspectives of the firm to investors, such as why earnings have changed, what liquidity needs the firm faces, what capital resources have been or are planned to be used, what material market risks the firm is exposed to" (Brown \& Tucker, 2011) and what are the future trends that may affect future operations.

We chose to consider risk related information at an aggregated level since the adoption of international standards of risk reporting in emerging markets is a vital step in their steady integration into the global economic system. It is also worthy to mention that out of our twelve investigated countries; eight countries have already required or allowed the use of IFRS by their listed financial firms. Besides, the literature on the financial sector shows that these firms disclose more comprehensive risk information relative to firms in other industries (e.g., Al-Hadi et al, 2017; Hirtle, 2007; Nier \& Baumann, 2006; Pérignon \& Smith, 2010). Not to mention that most Islamic banks in Bahrain, Jordan, Qatar, Saudi Arabia or Malaysia are either required to comply or moving toward embracing the AAOIFI and IFSB standards at a steady pace.

Scholars relied on different coding schemes when performing a content analysis. These schemes involve the use of either keywords, sentences or pages as a measurement unit. Congruent with recent risk disclosure literature (Beretta \& Bozzolan, 2004; Linsley \& Shrives, 2006; Amran et al., 2009; Dobler et al., 2011; Hussainey \& Elzahar, 2012; Moumen, Ben Othman \& Hussainey, 2015; 2016) we count the number of risk-related sentences to assess the level of risk disclosure by banks. We expect less bias when referring to sentences compared to words since Unerman (2000) suggests that words cannot be coded into different risk categories without reference to the sentence. 
Krippendorf (2007) argues further that "the meaning of a word typically depends on its syntactical role within a sentence".

An additional requirement for content analysis is the coding instrument. Our risk assessment instrument encompasses significant risk exposure for banks and focuses on eight types of disclosures, including capital structure, financial risk, operational risk, financial instruments, reserves, segment information, accounting and presentation policies and general risk information. We also incorporated two risk sub-components specific to Islamic banks. Extending Nahar, Azim and Jubb (2016), we develop our index from 4 main sources: the guidelines provided by the International Financial Reporting Standard (IFRS) 7, the Basel II: Market Discipline guideline, The AAOIFI and IFSB standards (specific to Islamic banks), and the accounting literature (Cabedo \& Tirado, 2004; Oliveria, et al. 2011; Barakat \& Hussainey, 2013; Abdallah et al, 2015). Typically, we adopted a two steps process. In the first step we made an extensive review of prior studies and identified the common items used to assess banks' risk disclosure.

We then cluster these items in accordance with regulatory requirements (IFRS 7; Basel II: Market discipline; AAOIFI and IFSB standards). In total our risk disclosure index includes 69 items grouped into 8 risk sub-categories. To measure the level of risk disclosure by banks, we assign to each of these risk items the number of sentences disclosed in banks' annual reports. We code risk disclosures any sentence that informs the reader about "any opportunity or prospect, or of any hazard, danger, harm, threat or exposure, that has already impacted or may impact upon the company, as well as the management of any such opportunity, prospect, hazard, harm, threat, or exposure" (Linsley \& Shrives, 2006).

We ensure the construct validity of our risk disclosure index and the reliability of our scores by following these procedures. First, as we previously stated, we derive the index categories and items 
from multiple and varied sources of information (IFRS, Basel II, AAOIFI, IFSB, prior literature). Second, to ensure reproducibility, one single coder performed the content analysis of banks' annual reports (Krippendorff, 2007). Third, an independent evaluator with financial reporting expertise coded a sub sample of 25 annual reports to ensure the reliability of the scale. Krippendroff (1980; 2007) argues that it is important that at least two researchers do this type of analysis independently and compare results for reliability checking. Fourth, we compare the risk Disclosure Index coded by both academics (the main researcher and the independent evaluator) to ascertain if there were any significant differences. Specifically, we perform an inter- rater reliability test to check for consistency in coding, and for accuracy of risk disclosures' scores. We rely on Krippendorff's alpha test, which is the most appropriate test of inter rater reliability (Hayes \& Krippendorff, 2007; Krippendorff, 2010). The test generates a Kalpha of 0.825 , a satisfactory level of inter-rater reliability for this intra-class agreement coefficient. It is common to require Kalpha $=0.80$ as the cut off point for a good reliability test, with a minimum of 0.67 (Krippendorff, 2007). 


\section{b. Independent variables:}

Table 1: Model specification and variable measurement

\begin{tabular}{llll}
\hline Abbreviated Name & Full Name & Variable description & Data source \\
\hline PSIA & The Profit Sharing Investment & Ratio of total deposits subscribing under the category of & Annual report \\
& Accounts & PSIA to total assets. & Annual report \\
\hline Non_PSIA & The non-Profit Sharing & Ratio of total deposits subscribing under the categories of & \\
& Investments Accounts & currents accounts and non-Investment accounts divided by & Zawya data base- bank \\
\hline BLOCK & Number of Blockholders & Number of blockholders- shareholders whose ownership & website-annual report \\
\hline HIGHEST_SH & Largest shareholder & Percent of shares owned by largest shareholders & Zawya data base- bank \\
& & & website-annual report \\
\hline FOREIGN & foreign ownership & Percent of shares owned by foreign shareholders & Zawya data base- bank \\
& & & Percent of shares owned by the government \\
\hline GOV & & & Zawya data base- bank \\
& Government ownership & website-annual report
\end{tabular}




\begin{tabular}{lllc}
\hline ROA & Return on assets & Net income/total assets & Annual report: \\
& & & Financial statements \\
\hline LEVERAGE & Leverage & Long-term debt/ total assets & Annual report: \\
& & & Financial statements \\
\hline BANKSIZE & Bank size & Natural logarithm of total assets & Annual report: \\
& & & Financial statements \\
\hline BKAGE & Bank age & Bank age & Bank website \\
\hline LIST & Listed bank & 1 if the IB is listed in the stock exchange, 0 otherwise & Stock exchange \\
\hline COUTRANSDEX & Business extent of disclosure & The index ranges from 0 to 10, with higher values & World Bank \\
& index & indicating more disclosure. & World Bank database \\
\hline GDP & Gross domestic products & & Annual report: \\
\hline AAOIFI & AAOIFI standards adoption & 1if the IB use AAOIFI standards, 0 otherwise & Financial statements \\
\hline
\end{tabular}




\subsection{Research methodology}

To empirically investigate the relationship between risk disclosure, firm attributes, deposit structure and ownership structure, we use the following GLS regression and GMM transformed multiple regression models:

$\mathrm{RD}_{\mathrm{i}}=\alpha \mathrm{i}+\beta_{1} \mathrm{BLOCK}+\beta_{2} \mathrm{FORGN}+\beta_{3} \mathrm{GOV}+\beta_{4}$ HIGHEST_SH $+\beta_{4}$ PSIA $+\beta_{6} \mathrm{ROA}+\beta_{7}$

LEVERAGE $+\beta_{8}$ BANKSIZE $+\beta_{9}$ BKAGE $+\beta_{10}$ LIST $+\beta_{11}$ COUTRANSDEX $+\beta_{12}$ GDP $+\beta_{13}$ $\mathrm{AAOIFI}+\varepsilon \mathrm{i}$

where $\mathrm{RD}_{\mathrm{i}}$ : is Risk Disclosure index for bank i, Block: is the number of Blockholders for bank i, HIGHEST_SH: is the Percent of shares owned by largest shareholders ; FORGN: Percent of shares owned by foreign shareholders for bank i, GOV: Percent of shares owned by the government for bank i, PSIA: ratio of total Profit-Sharing Investment account divided by total assets for bank i, ROA: ratio of net income/ total assets , LEVERAGE: ratio of long-term debt/ total assets for bank i, BANKSIZE: Natural logarithm of total assets for bank i, BANKAGE: is the age of bank i, LIST: 1 if the bank is listed in the stock exchange, 0 otherwise, COUTRANSDEX: The index ranges from 0 to 10, with higher values indicating more disclosure ,AAOIFI: equal to 1 if the bank i use AAOIFI standards, 0 otherwise, GDP: is the logarithm napierian of the Gross domestic products for each country in the concerned year.

We use the first-order Taylor-series linearisation method to control for heterosedasticity and to produce robust standard errors. In addition, we use both lagged and contemporaneous independent variables in Eq. (2). Finally, we use the Ramsey RESET test for omitted variables and model misspecification, we also use the variance inflation factors (VIF) to examine whether the independent variables are perfectly collinear. 
We used, also, the above regression models to examine the association between RD subcategories and ownership structure variables. We used the transformed GMM multiple regression for the following sub categories of RD (D1: Capital structure and adequacy; D2: Financial risk; D3: Operational risk; D4: Financial instruments; D5: Reserves; D6: Segment Information; D7: Accounting and presentation policies; D8: General risks information).

\section{Empirical results:}

\subsection{Descriptive statistics}

In this section, we analyze the results of the risk disclosure index of the 71 Islamic banks during the period from 2009 to 2014 . Table 2 presents the descriptive statistics of the risk disclosure Index scores across countries. The results show that, over the years 2009 to 2014, the average aggregate risk disclosure is 366.1. The index scores show that the extent of disclosure across countries varies considerably. Turkey has the highest risk disclosure index score of 662.3 , followed by Malaysia at 617.4 and Pakistan 448.7. The lowest scores are achieved by Tunisia and Egypt, 20 and 167.8 respectively.

Table 3 presents the weighted average risk disclosure index scores during 2009-2014. As reflected in the analysis of the country's risk disclosure, we find that the financial risk dimension generally scores highly across all countries whilst the Segment Information scores the lowest. The highest disclosure score relates to the financial risk dimension (D2) which is 182.59 for our sample of Islamic banks followed by the scores of financial instruments (D4) and accounting and presentation policies (D7). On the other hand, the lowest disclosure score relates to-Segment Information (D6) which has a weighted average score of 0.86 for Islamic banks constituting our 
sample. This finding is consistent with the perception that banks pay relatively little attention to segments information whereas the financial risk, financial instruments and accounting and presentation policies are areas that successful banks which want to comply with best practice risk management would place significant emphasis on.

Table 4 reports the evolution of risk disclosure index over the period of study. It is clearly observed that the average risk disclosure index has increased over the 6 years of observation from 333.9 in 2009 to 491.3 in 2014. Similarly, the weighted average risk disclosure of the sub-index scores (dimensions) has increased considerably over the years.

Table 5 presents the descriptive statistics of the covariates during 2009-2014. The average risk disclosure index ranges from 10 to 1684 with an average of 366.1. Return on assets (ROA) ranges from $-15 \%$ to $52 \%$ with an average $2 \% .46 \%$ of banks constituting our sample are listed in the stock exchange. The average age of the banks constituting our sample is 18 years old. The average leverage is $64 \%$. The average countries disclosure index is 7.5 (with a minimum of 4 and maximum of 10). On average, $54 \%$ of the banks constituting our sample use AAOIFI standards.

Table 5 also reports that the number of block holders range from 0 to 7 with an average of 2 and on average the highest shareholders own $54.1 \%$ of the shares. On average foreign ownership represents $49 \%$ of the total share and government shareholders represent $16.3 \%$. The share of PSIA account holders count $36.9 \%$ of total assets.

Table 6 reports the outputs of the correlation matrix of the covariates used in the analysis. It is clear that there are no significant correlation coefficients greater than $50 \%$, therefore our estimation is not subject to multicollinearity problem. 


\subsection{Regression results}

Table 7 reports the cross-sectional GLS and GMM regressions results for risk disclosure score and Table 8 reports the results for the 8 subcategories of risk disclosure.

Table 7 presents, also, the R2, F-ratio, $\beta$-coefficients and t-statistics for our main model. The Fisher' test is significant in the four GLS models. As reported in Table 7, the GLS model for the overall risk disclosure score indicated an adjusted coefficient of determination (R2) 89.3\% for GLS estimation and 86.3 for GMM estimation.

For the ownership concentration, we find that there is a negative association between the number of block holders and risk disclosure and between the highest shareholder and risk disclosure. Therefore, hypothesis $\mathrm{H} 1$ and $\mathrm{H} 2$, which stipulates that risk disclosure increases with the reductions in number of blockholders, are supported. Our finding is consistent with Lopes \& Rodrigues (2007); Oliveira et al. (2011); and Ntim et al., (2013). Blockholders do have superior access to private information including risk disclosure, reducing hence bank management's incentive to disclose such information in their annual reports. As powerful investors, block owners might have other efficient means of communicating with banks' management, for example, oneto-one meetings.

Moreover, we find that there is a positive association between foreign ownership and risk disclosure. Hence, hypothesis H3 is supported. Our finding is consistent with Haniffa \& Cooke (2002); and Barako et al. (2006) findings. Higher level of foreign ownership increases corporate disclosure. Information asymmetry should decline with an increase in foreign ownership while there is an increase in general transparency in the market. 
Regarding government ownership, we do not find any association between government ownership and risk disclosure. Then, hypothesis $\mathrm{H} 4$ is rejected.

With regards to deposit structure, we find that there is a significant and positive association between PSIA and risk disclosure. Thus, hypothesis H5 is accepted. Islamic banks, as equity-based capital structures dominated by shareholders equity and PSIAs holders are exposed greatly to the massive risk of the withdrawal of funds which threatens their respective positions. The Islamic banks increasing their disclosures might maintain the holders of PSIAs. Our finding is consistent with Grassa (2018) findings. High concentration of PSIA influence the level of firm disclosure. Moreover, our finding is in line with Magalha es \& Al-Saad's (2013) study which showed that the majority of Islamic banks believed that the quarterly audited financial reports with detailed explanations of each item were sufficient information for PSIAs holders. However, as reported by Magalhaes \& Al-Saad (2013), the practices, implemented by Islamic banks to protect the rights of holders of PSIAs, are not effective enough in the light of the standard CG principles.

In relation to our control variables, we find that leverage is negatively associated to risk disclosure. This implies that the level of risk disclosure is not largely influenced by the GCC Islamic banks' agency costs of debt. Our finding is consistent with Aksu \& Kosedag's (2006) findings for the Turkish firms. We find, also, a positive association between Islamic bank size and risk disclosure. Generally, it is expected that larger banks disclose risk information more often than smaller ones. Indeed, larger banks can afford the costs to improve risk disclosure and have more incentive to enhance their reputations. This result is consistent with previous studies (Dhouibi \& Mamoghli, 2013; Aksu \& Kosedag, 2006). Profitability is not significant in explaining risk disclosure. Our finding is consistent with Samaha \& Dahawy's (2010) findings. However, there is a positive and significant association between Islamic bank age and risk disclosure. This implies that older 
Islamic banks disclose more information about risk than younger Islamic banks. AAOIFI adoption, countries transparency index and GDP growth influence positively the level of risk disclosure.

Table 8 reports the results for the 8 subcategories of risk disclosure. The findings of our sub model support the results of our main regression. 


\section{Conclusion:}

This study contributes to recent Islamic finance and disclosure literature by offering empirical evidence on the impact of firm characteristics, ownership concentration and deposits structure on risk disclosure for a large sample of 71 Islamic banks operating in 12 countries (namely, Bahrain, Indonesia, Jordan, Kuwait, Malaysia, Pakistan, Qatar, Saudi Arabia, Tunisia, Egypt, Turkey and UAE) which were observed over the period from 2009 to 2014.

In terms of overall disclosure practice, we find that the overall risk disclosure index increased over the 6 years of observations. Furthermore, the index scores show that the extent of disclosure across countries varies considerably. Turkey has the highest risk disclosure index score, followed by Malaysia and Pakistan. The lowest scores are achieved by Tunisia and Egypt. Moreover, we find that Islamic banks pay relatively little attention to segments information whereas the financial risk, financial instruments and accounting and presentation policies are areas that successful banks which want to comply with best practice risk management would place significant emphasis on. Our findings invite bankers and the supervisory bodies to make a greater effort to improve the level of risk disclosure for Islamic banks. Low level of disclosure can result of the novelty of the idea of disclosure and transparency for the Islamic finance industry.

With regard to the determinants of risk disclosure, we find that the extent of risk disclosure of Islamic banks:

(i) is lower for Islamic banks with higher ownership concentration, as measured by the number of block holders and highest shareholder ownership, higher leveraged bank as well as for listed Islamic banks 
(ii) Increases with Islamic banks with higher concentrations of PSIA, higher foreign ownership, bank size, bank age, the country transparency index, GDP and AAOIFI adoption.

By disaggregating total risk disclosure into the 8 sub-categories, we are able to specify, also, the components of risk disclosure impacted by various determinants.

Our paper findings provide many policy implications. First, through the optimization of the ownership structure (dispersed ownership) regulators have to improve the Islamic banking system's risk disclosure mechanisms in Islamic banking system in order to promote transparency and disclosure. Secondly, regulators and policy makers should revise guidelines with the main purpose of protecting holders of PSIAs (considered to be minor shareholders without voting power) through promoting risk disclosure and transparency. Thirdly, our findings can be useful for many international supervisory bodies, like the IFSB and AAOIFI, in evaluating transparency and disclosure standards.

This paper's findings are is subject, also, to a number of limitations. Firstly, there was manual scoring of annual reports (subjectivity). Secondly, while some items might have higher information content or be more useful than others for users of Islamic banks' annual reports, no weighting is assigned to items. Thirdly, the research focuses exclusively on the 12 countries and excludes the other Middle East, Southeast Asia and Far East countries where ownership structure and deposits structure might affect risk disclosure differently.

Despite this paper's limitations, the authors feel that he has given an important contribution to the literature on risk disclosure and governance in Islamic finance by moving the discussion forward on this topic through field work and analysis of the empirical data. Our findings may be regarded 
as a pilot to serve as the basis for further research employing a larger sample and investigating other contexts.

On behalf of all authors, the corresponding author states that there is no conflict of interest. 


\section{References:}

Abdallah, A. A.N. et al. (2015). Islamic financial institutions, corporate governance, and corporate risk disclosure in Gulf Cooperation Council countries. Journal of Multinational Financial Management, 31, 63-82.

Abdel Karim, R.A. (2001). International accounting harmonisation banking regulation, and Islamic banks', The International Journal of Accounting, 36 (2), 169-93.

Aksu M and Kosedag A, (2006).Transparency and Disclosure Scores and their Determinants in the Istanbul Stock Exchange. Corporate Governance: An International Review, 14 (4), 277-296.

Al-Hadi A. et al. (2015). Risk Committee, Firm Life Cycle, and Market Risk Disclosures. Corporate Governance: An International Review, 24(2), 145-170.

Al-Hadi, A., et al. (2017). Market risk disclosures and corporate governance structure: Evidence from GCC financial firms. The Quarterly Review of Economics and Finance.

Al-Janadi, Y., et al. (2016), "Does government ownership affect corporate governance and corporate disclosure? Evidence from Saudi Arabia", Managerial Auditing Journal, Vol. 31 Nos 8/9, pp. 871-890.

Amran, A., et al. (2009). Risk reporting: An exploratory study on risk management disclosure in Malaysian annual reports. Managerial auditing journal, 24(1).

Archer, S. and Karim, R.A.A. (2009). Profit-sharing investment accounts in Islamic banks: regulatory problems and possible solutions. Journal of Banking Regulation, 10, 300-306.

Archer, S., Karim, A.A.R. and Sundararajan, V. (2010), "Supervisory, regulatory, and capital adequacy implications of profit-sharing investment accounts in Islamic finance', Journal of Islamic Accounting and Business Research, 1(1), 10-31.

Barakat, A., \& Hussainey, K. (2013). Bank governance, regulation, supervision, and risk reporting: Evidence from operational risk disclosures in European banks. International Review of Financial Analysis, 30, 254-273.

Barako, D. G et al. (2006). Factors Influencing Voluntary Corporate Disclosure by Kenyan Companies. Corporate Governance: An International Review, 14(2), 107-125.

Beretta, S., \& Bozzolan, S. (2004). A framework for the analysis of firm risk communication. The International Journal of Accounting, 39(3), 265-288.

Birt, J. L. et al. (2006). Ownership, Competition, and Financial Disclosure. Australian Journal of Management, 31(2), 235-263. 
Branco, M. C., \& Rodrigues, L. L. (2006). Corporate Social Responsibility and ResourceBased Perspectives. Journal of Business Ethics, 69(2), 111-132.

Brown, S. V., \& Tucker, J. W. (2011). Large-Sample Evidence on Firms' Year-over-Year MD\&A Modifications. Journal of Accounting Research, 49(2), 309-346.

BSCB (2012) "Core principles for effective banking supervision". https://www.bis.org/publ/bcbs230.htm

Cabedo, J. D., \& Tirado, J. M. (2004). The disclosure of risk in financial statements. Accounting Forum, 28(2), 181-200.

Carpenter, V. L., \& Feroz, E. H. (2001). Institutional theory and accounting rule choice: an analysis of four US state governments' decisions to adopt generally accepted accounting principles. Accounting, Organizations and Society, 26(7), 565-596.

Chatterjee, B., Tooley, S., Fatseas, V., \& Brown, A. (2012). An Analysis of the Qualitative Characteristics of Management Commentary Reporting by New Zealand Companies. Australasian Accounting, Business and Finance Journal, 5(4), 43-64.

Chen, J. C., \& Roberts, R. W. (2010). Toward a More Coherent Understanding of the Organization-Society Relationship: A Theoretical Consideration for Social and Environmental Accounting Research. Journal of Business Ethics, 97(4), 651-665.

Choe, H. et al. (2005). Do Domestic Investors Have an Edge? The Trading Experience of Foreign Investors in Korea. The Review of Financial Studies, 18(3), 795-829.

Choi, J. J., Lam, K. C. K., Sami, H., \& Zhou, H. (2013). Foreign Ownership and Information Asymmetry. Asia-Pacific Journal of Financial Studies, 42(2), 141-166.

Deegan, C. (2002). Introduction: The legitimising effect of social and environmental disclosures - a theoretical foundation. Accounting, Auditing \& Accountability Journal, 15(3), 282-311.

Deegan, C., \& Gordon, B. (1996). A Study of the Environmental Disclosure Practices of Australian Corporations. Accounting and Business Research, 26(3), 187-199.

Dhouibi, R., \& Mamoghli, C. (2013). Determinants of Voluntary Disclosure in Tunisian Bank's Reports. Research Journal of Finance and Accounting, 4(5), 80-94.

Dobler, M., et al. (2011). Attributes of Corporate Risk Disclosure: An International Investigation in the Manufacturing Sector. Journal of International Accounting Research, 10(2), $1-22$.

Dowling, J., \& Pfeffer, J. (1975). Organizational Legitimacy: Social Values and Organizational Behavior. The Pacific Sociological Review, 18(1), 122-136. 
Edmans, A. (2014). Blockholders and Corporate Governance. Annual Review of Financial Economics, 6(1), 23-50.

Fernández-Alles, M., \& Valle-Cabrera, R. (2006). Reconciling institutional theory with organizational theories: How neoinstitutionalism resolves five paradoxes. Journal of Organizational Change Management, 19(4), 503-517.

Grassa, R. (2018). Deposits structure, ownership concentration and corporate governance disclosure in GCC Islamic banks: Empirical evidence. Journal of Islamic Accounting and Business Research, 9(4), 587-606.

Grassa, R., Chakroun, R. and Hussainey, K. (2018). Corporate governance and Islamic banks' products and services disclosure. Accounting Research Journal, 31, 75-89.

Grassa, R., El-Halaby, S. and Hussainey, K. (2019). Corporate governance and multicorporate disclosures evidence from Islamic Banks. Research in Corporate and Shariah Governance in the Muslim World: Theory and Practices.

Hamza, H. \& Saadaoui, Z. (2013). Investment deposits, risk-taking and capital decisions in Islamic banks. Studies in Economics and Finance, 30(3), 244-265.

Haniffa, R. \& Cooke, T.E. (2002). Culture, Corporate Governance and Disclosure in Malaysian Corporations, Abacus, 38 (3), 317-349.

Hassan, M. K. (2008). The corporate governance inertia: the role of management accounting and costing systems in a transitional public health organization. In Corporate Governance in Less Developed and Emerging Economies (Vol. 8, p. 409-454).

Hayes, A. F., \& Krippendorff, K. (2007). Answering the Call for a Standard Reliability Measure for Coding Data. Communication Methods and Measures, 1(1), 77-89.

Healy, P. M., \& Palepu, K. G. (2001). Information asymmetry, corporate disclosure, and the capital markets: A review of the empirical disclosure literature. Journal of Accounting and Economics, 31(1), 405-440.

Hirtle, B. (2007). Public Disclosure, Risk, and Performance at Bank Holding Companies (Scholarly Paper No. ID 1003219). Rochester, NY. https://papers.ssrn.com/abstract=1003219

Huafang, X., \& Jianguo, Y. (2007). Ownership structure, board composition and corporate voluntary disclosure: Evidence from listed companies in China. Managerial Auditing Journal, 22(6), 604-619.

Jensen, M. C., \& Meckling, W. H. (1976). Theory of the firm: Managerial behavior, agency costs and ownership structure. Journal of Financial Economics, 3(4), 305-360. 
Jiang, L., \& Kim, J.-B. (2004). Foreign Equity Ownership and Information Asymmetry: Evidence from Japan. Journal of International Financial Management \& Accounting, 15(3), 185-211.

Kaplan, S. E., \& Ruland, R. G. (1991). Positive theory, rationality and accounting regulation. Critical Perspectives on Accounting, 2(4), 361-374.

Krippendorff, K. (1980). Validity in Content Analysis. Computerstrategien für die Kommunikationsanalyse, 69-112.

Krippendorff, K. (2007). Reliability in Content Analysis. Human Communication Research, 30(3), 411-433.

Krippendorff, K. (2010). On Communicating: Otherness, Meaning, and Information. Routledge.

Lindblom C.K. (1994) "The implications of organizational legitimacy for corporate social performance and disclosure", Paper presented at the Critical Perspectives on Accounting Conference, New York.

Linsley, P. M., \& Shrives, P. J. (2003). Risk reporting by German and UK companies: hot air or meaningful disclosure. Paper presented at Financial Reporting and Business Communication conference, Cardiff, United Kingdom.

Linsley, P. M., \& Shrives, P. J. (2006). Risk reporting: A study of risk disclosures in the annual reports of UK companies. British Accounting Review, 38, 387-404.

Linsley, P., \& Kajuter, P. (2008). Restoring reputation and repairing legitimacy: a case study of impression management in response to a major risk event at Allied Irish Banks plc. International Journal of Financial Services Management, 3(1), 65-82.

Linsmeier, et al. (2002). The effect of mandated market risk disclosures on trading volume sensitivity to interest rate, exchange rate, and commodity price movements. The Accounting Review, 77(2), $343-377$.

Lopes, P. T., \& Rodrigues, L. L. (2007). Accounting for financial instruments: An analysis of the determinants of disclosure in the Portuguese stock exchange. The International Journal of Accounting, 42(1), 25-56.

Magalhães, R., \& Al-Saad, S. (2013). Corporate governance in Islamic financial institutions: The issues

Magness, V. (2006). Strategic posture, financial performance and environmental disclosure: An empirical test of legitimacy theory. Accounting, Auditing \& Accountability Journal, 19(4), 540-563. 
Malatesta, D., \& Smith, C. R. (2014). Lessons from Resource Dependence Theory for Contemporary Public and Nonprofit Management. Public Administration Review, 74(1), 14-25.

Mohobbot A.M., (2005). Corporate risk reporting practices in annual reports of Japanese companies. Japanese Journal of Accounting, 113-133.

Moumen, N., Ben Othman, H., \& Hussainey, K. (2015). The value relevance of risk disclosure in annual reports: Evidence from MENA emerging markets. Research in International Business and Finance, 34(C), 177-204.

Moumen, N., Ben Othman, H., \& Hussainey, K. (2016). Board structure and the informativeness of risk disclosure: Evidence from MENA emerging markets. Advances in Accounting, 35, 82-97.

Mousa, G. A., \& Elamir, E. A. H. (2014). The effect of governance mechanisms on the quality of risk disclosure: using bootstrap techniques. American Journal of Finance and Accounting, 3(2/3/4), 128-151.

Nahar, S., Azim, M., \& Jubb, C. (2016). The determinants of risk disclosure by banking institutions: Evidence from Bangladesh. Asian Review of Accounting, 24(4), 426-444.

Neifar, S., \& Jarboui, A. (2017). Corporate governance and operational risk voluntary disclosure: Evidence from Islamic banks. Research in International Business and Finance, 46, 4354.

Nier, E., \& Baumann, U. (2006). Market discipline, disclosure and moral hazard in banking. Journal of Financial Intermediation, 15(3), 332-361.

Nobanee, H., \& Ellili, N. (2017). Anti-money laundering disclosures and banks' performance. Journal of Financial Crime, 25(1), 95-108.

Ntim, C. G. et al. (2013). Corporate governance and risk reporting in South Africa: A study of corporate risk disclosures in the pre- and post-2007/2008 global financial crisis periods. International Review of Financial Analysis, 30, 363-383.

Oliveira, J. et al. (2011a). Risk-related disclosure practices in the annual reports of Portuguese credit institutions: An exploratory study. Journal of Banking Regulation, 12(2), 100-118.

Oliveira, J. et al. (2011b). Voluntary risk reporting to enhance institutional and organizational legitimacy: Evidence from Portuguese banks. Journal of Financial Regulation and Compliance, 19(3), 271-289.

Oliveira, J. et al. (2013). Risk reporting: a literature review (working Paper) (p. 1-58). http://repositorium.sdum.uminho.pt/handle/1822/23683 
Pérignon, C., \& Smith, D. (2010). The level and quality of Value-at-Risk disclosure by commercial banks. Journal of Banking \& Finance, 34(2), 362-377.

Pfeffer, J. (1972). Size and Composition of Corporate Boards of Directors: The Organization and its Environment. Administrative Science Quarterly, 17(2), 218-228.

Pfeffer, J., \& Salancik, G. R. (1978). The External Control of Organizations: A Resource Dependence Perspective. (Working Paper). https://papers.ssrn.com/abstract=1496213

Pfeffer, J., \& Salancik, G. R. (2003). The External Control of Organizations: A Resource Dependence Perspective. Stanford University Press.

Pirson, M., \& Turnbull, S. (2011). Corporate Governance, Risk Management, and the Financial Crisis: An Information Processing View. Corporate Governance: An International Review, 19(5), 459-470.

Price Waterhouse Coopers (2008) "A Practical Guide to Risk Assessment". https://web.actuaries.ie/press/erm-resource-database/practical-guide-risk-assessment

Samaha, K., \& Dahawy, K. (2011). An empirical analysis of corporate governance structures and voluntary corporate disclosure in volatile capital markets: The Egyptian experience. International Journal of Accounting, Auditing and Performance Evaluation, 7(1-2), 61-93.

Sami, H., \& Zhou, H. (2004). A comparison of value relevance of accounting information in different segments of the Chinese stock market. The International Journal of Accounting, 39(4), 403-427.

Sepasi, S., et al. (2016), "Ownership structure and disclosure quality: case of Iran", Procedia Economics and Finance, Vol. 36, pp. 108-112.

Suchman, M. C. (1995). Managing Legitimacy: Strategic and Institutional Approaches. The Academy of Management Review, 20(3), 571-610.

surrounding unrestricted investment account holders. Corporate Governance (Bingley), 13(1), 39-57.

Uddin, M. H., \& Hassan, M. K. (2011). Corporate risk information in annual reports and stock price behavior in the United Arab Emirates. Academy of Accounting and Financial Studies, 15(1), 59-84.

Unerman, J. (2000). Methodological issues - Reflections on quantification in corporate social reporting content analysis. Accounting, Auditing \& Accountability Journal, 13(5), 667-681.

Visser, H. Islamic Finance. Edward Elgar Publishing, Northampton (2009).

Watts, R. L., \& Zimmerman, J. L. (1978). Towards a Positive Theory of the Determination of Accounting Standards. The Accounting Review, 53(1), 112-134. 
Watts, R. L., \& Zimmerman, J. L. (1986). Positive Accounting Theory. Englewood Cliffs, N.J. : Prentice-hall.

Watts, R., \& Zimmerman, J. L (1983). Agency Problems, Auditing, and the Theory of the Firm: Some Evidence. Journal of Law and Economics, 26(3), 613-633.

Yang, S. U. (2007). An integrated model for organization-public relational outcomes, organizational reputation, and their antecedents. Journal of PublicC61:C87+C82:C87 Relations Research, 19, 91-121. 


\section{Appendix}

Table 2: Descriptive statistics of the risk disclosure Index by country.

\begin{tabular}{|c|c|c|c|c|c|}
\hline & Mean & Std.dev & Min & Max & $\begin{array}{c}\text { Numb of } \\
\text { observed banks }\end{array}$ \\
\hline \multicolumn{6}{|l|}{ Aggregate RD Index } \\
\hline & 366.1 & 153.6 & 117.0 & 731.0 & 71 \\
\hline \multicolumn{6}{|l|}{ Qatar } \\
\hline & 239.8 & 96.9 & 148.0 & 402.0 & 4 \\
\hline \multicolumn{6}{|l|}{ Bahrain } \\
\hline & 365.0 & 148.0 & 7.0 & 657.0 & 23 \\
\hline \multicolumn{6}{|l|}{ Egypt } \\
\hline & 167.8 & 143.4 & 13.0 & 327.0 & 2 \\
\hline \multicolumn{6}{|l|}{ Jordan } \\
\hline & 257.6 & 42.6 & 182.0 & 318.0 & 2 \\
\hline \multicolumn{6}{|l|}{ Kuwait } \\
\hline & 414.6 & 129.0 & 98.0 & 654.0 & 5 \\
\hline \multicolumn{6}{|l|}{ Malaysia } \\
\hline & 617.4 & 311.1 & 17.0 & 1684.0 & 15 \\
\hline \multicolumn{6}{|l|}{ Pakistan } \\
\hline & 448.7 & 163.8 & 292.0 & 680.0 & 2 \\
\hline \multicolumn{6}{|l|}{ Saudi Arabia } \\
\hline & 419.7 & 152.7 & 66.0 & 656.0 & 6 \\
\hline \multicolumn{6}{|l|}{ Tunisia } \\
\hline & 20.0 & 15.2 & 1.0 & 42.0 & 2 \\
\hline \multicolumn{6}{|l|}{ Turkey } \\
\hline & 662.3 & 317.1 & 234.0 & 1284.0 & 4 \\
\hline \multicolumn{6}{|l|}{ United Arab } \\
\hline Emirates (UAE) & 414.5 & 169.6 & 230.0 & 1345.0 & 10 \\
\hline
\end{tabular}


Table 3: Weighted average risk disclosure Index by dimension during 2009-2014

\begin{tabular}{lrrrrrrrr}
\hline & D1 & D2 & D3 & D4 & D5 & D6 & D7 & D8 \\
\hline Aggregate RD Index & 25.29 & 182.59 & 9.76 & 82.06 & 20.38 & 0.86 & 73.48 & 14.57 \\
Qatar & 3.38 & 93.75 & 1.94 & 60.13 & 6.75 & 0.00 & 45.81 & 12.94 \\
Bahrain & 23.70 & 153.60 & 8.98 & 72.03 & 8.80 & 0.18 & 70.73 & 15.06 \\
Egypt & 10.37 & 52.40 & 5.88 & 26.42 & 6.95 & 4.65 & 32.00 & 1.82 \\
Jordan & 7.17 & 84.58 & 7.67 & 91.92 & 9.58 & 0.00 & 29.42 & 13.92 \\
Kuwait & 22.88 & 182.28 & 6.44 & 95.76 & 8.48 & 0.20 & 77.48 & 13.64 \\
Malaysia & 21.93 & 271.41 & 16.23 & 124.54 & 29.21 & 0.00 & 122.75 & 10.25 \\
Pakistan & 67.71 & 182.67 & 28.04 & 27.68 & 5.05 & 0.80 & 90.92 & 14.67 \\
Saudi Arabia & 11.74 & 224.85 & 7.65 & 96.50 & 16.50 & 1.62 & 45.41 & 14.38 \\
Tunisia & 0.50 & 0.00 & 0.00 & 0.00 & 1.25 & 0.00 & 0.00 & 0.00 \\
Turkey & 34.50 & 305.71 & 2.93 & 92.14 & 87.50 & 1.14 & 108.93 & 29.43 \\
United Arab Emirates (UAE) & 74.37 & 457.19 & 21.56 & 215.59 & 44.04 & 0.83 & 184.83 & 34.14 \\
\hline
\end{tabular}

D1: Capital structure and adequacy; D2: Financial risk; D3: Operational risk; D4: Financial instruments; D5: Reserves; D6: Segment Information; D7: Accounting and presentation policies; D8: General risks information; 
Table 4: Descriptive statistics of the risk disclosure Index by year:

\begin{tabular}{lcccccc}
\hline & $\mathbf{2 0 0 9}$ & $\mathbf{2 0 1 0}$ & $\mathbf{2 0 1 1}$ & $\mathbf{2 0 1 2}$ & $\mathbf{2 0 1 3}$ & $\mathbf{2 0 1 4}$ \\
\hline Aggregate risk & 333.9 & 367.2 & 396.8 & 429.4 & 489.0 & 491.3 \\
disclosure Index & & & & & & \\
D1 & 16.6 & 18.2 & 18.6 & 20.1 & 23.6 & 24.8 \\
D2 & 141.6 & 167.3 & 176.2 & 192.8 & 213.5 & 211.0 \\
D3 & 10.8 & 11.6 & 12.1 & 12.0 & 12.9 & 9.9 \\
D4 & 61.6 & 65.0 & 80.3 & 87.6 & 102.8 & 102.0 \\
D5 & 15.4 & 15.4 & 13.6 & 17.6 & 21.4 & 19.1 \\
D6 & 1.3 & 1.2 & 1.2 & 0.9 & 1.0 & 0.4 \\
D7 & 58.8 & 66.2 & 71.5 & 81.1 & 87.6 & 81.5 \\
D8 & 10.0 & 12.3 & 12.6 & 13.9 & 15.5 & 17.5 \\
\hline
\end{tabular}

D1: Capital structure and adequacy; D2: Financial risk; D3: Operational risk; D4: Financial instruments; D5: Reserves; D6: Segment Information; D7: Accounting and presentation policies; D8: General risks information; 
Table 5: Descriptive statistics.

\begin{tabular}{lrrrrr}
\hline & AVERAGE & MEDIAN & Sted.dev & \multicolumn{1}{l}{ MIN } & \multicolumn{1}{c}{ MAX } \\
\hline RD & 366.1 & 398.50 & 242.38 & 1.00 & 1684.00 \\
ROA (\%) & 0.02 & 0.01 & 0.06 & -0.15 & 0.52 \\
LIST & 0.46 & 0.00 & 0.50 & 0.00 & 1.00 \\
BKAGE & 18 & 12 & 16 & 1 & 61 \\
LEVERAGE & 0.64 & 0.67 & 0.23 & 0.00 & 1.42 \\
COUTRANSDEX & 7.50 & 8.00 & 2.16 & 4.00 & 10.00 \\
PSIA & 0.369 & 0.204 & 0.599 & 0.05 & 0.763 \\
BLOCK & 2.25 & 1.00 & 1.64 & 0.00 & 7.00 \\
HIGHEST_SH & 0.541 & 0.47 & 0.339 & 0.0418 & 1.00 \\
FOREIGN & 0.49 & 0.231 & 0.44 & 0.00 & 1.00 \\
GOV & 0.163 & 0 & 0.281 & 0 & 1 \\
AAOIFI & 0.537 & 1 & 0.49 & 0 & 1 \\
\hline
\end{tabular}

RD: risk disclosure, ROA: Net income/ total assets; LIST: 1 if the bank is listed in the stock exchange, 0 otherwise; BANKSIZE: Natural logarithm of total assets; BKAGE: Number of years; LEVERAGE: Longterm debt/ total assets; BlOCK: number of blokholders, HIGHEST_SH: highest shareholder ownership, GOV: government ownership; FOREIGN: Percent of shares owned by foreign shareholders; PSIA: Profit Sharing Investment Accounts; GDP: Natural logarithm of Gross domestic products; COUTRANSDEX: The index ranges from 0 to 10, with higher values indicating more disclosure.; AAOIFI: AAOIFI standards adoption 


\section{Table 6: Correlation matrix.}

\begin{tabular}{|c|c|c|c|c|c|c|c|c|c|c|c|c|c|c|}
\hline & $\underline{\simeq}$ & $\underset{\underline{z}}{\overleftarrow{g}}$ & $\stackrel{5}{3}$ & 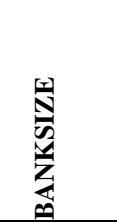 & 矛 & 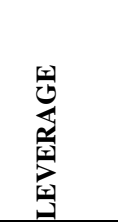 & 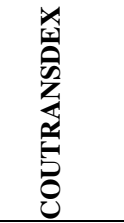 & ِِ & 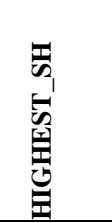 & $\begin{array}{l}Z \\
\mathbf{Z} \\
0 \\
0 \\
0 \\
0\end{array}$ & 己े & $\mathbb{\pi}$ & 亏ิ & $\frac{1}{2}$ \\
\hline RD & 1.000 & $-0.160 *$ & -0.050 & $0.207 * *$ & 0.034 & 0.091 & 0.446 & $-0.164 * *$ & 0.077 & 0.072 & 0.065 & 0.170* & 0.103 & $-0.341 * *$ \\
\hline ROA & -0.064 & 1.000 & 0.026 & $0.167 *$ & 0.250 & $0.232 * *$ & $-0.118 *$ & $0.185^{*}$ & -0.069 & $-0.069 *$ & 0.084 & $-0.152 *$ & 0.045* & 0.023 \\
\hline LIST & 0.010 & 0.006 & 1.000 & $0.336 * *$ & 0.201 & $0.195 * *$ & $-0.416^{* * *}$ & $0.241 *$ & -0.418 & $-0.412 * *$ & 0.034 & -0.007 & -0.179 & 0.031 \\
\hline BANKSIZE & $-0.110 * *$ & -0.015 & -0.084 & 1.000 & 0.568 & $0.371 * *$ & -0.044 & 0.017 & -0.429 & -0.429 & 0.254 & $0.345^{* *}$ & 0.095 & $-0.433 * * *$ \\
\hline BKAGE & $0.192 *$ & 0.008 & $0.220 * *$ & 0.075 & 1.000 & $0.257 *$ & $-0.119 *$ & -0.005 & -0.256 & $-0.253 *$ & 0.188 & 0.072 & $0.027 * *$ & -0.090 \\
\hline LEVERAGE & $-0.026^{*}$ & 0.039 & $0.227^{*}$ & -0.087 & $0.308 * *$ & 1.000 & -0.056 & 0.074* & -0.186 & -0.186 & $-0.020 * *$ & 0.152 & $0.042^{* *}$ & -0.035 \\
\hline COUTRANSDEX & $0.426 * *$ & -0.009 & $-0.358 * *$ & $-0.139 *$ & -0.095 & -0.063 & 1.000 & -0.229 & -0.336 & $0.256 * *$ & -0.185 & 0.094 & 0.165 & $-0.362 * *$ \\
\hline BLOCK & $-0.207 * *$ & -0.079 & $0.088 * *$ & 0.039 & $0.136 * *$ & -0.122 & $-0.144 * *$ & 1.000 & -0.376 & $-0.143 * *$ & $\mathbf{0 . 3 1 7} * * *$ & $-0.332 * *$ & 0.345 & $0.196 *$ \\
\hline HIGHEST_SH & $0.129 *$ & -0.073 & $-0.435 * * *$ & 0.063 & $-0.200 * *$ & 0.067 & $0.283 * *$ & -0.453 & 1.000 & 0.192 & -0.046 & $0.372 * *$ & $-0.033 * *$ & $-0.212 * *$ \\
\hline FOREIGN & 0.026 & 0.095 & $-0.345 * *$ & 0.056 & $0.247 * *$ & $-0.285^{* *} *$ & $0.325 * * *$ & $-0.032 *$ & 0.154 & 1.000 & -0.320 & -0.203 & 0.036 & $0.145^{*}$ \\
\hline GOV & 0.048 & -0.071 & $-0.052 *$ & 0.026 & $0.300 * *$ & $-0.024 * *$ & 0.006* & $0.081 *$ & 0.166 & -0.327 & 1.000 & 0.106 & 0.014 & 0.065 \\
\hline PSIA & 0.238 & $-0.062 * *$ & $-0.078 *$ & $0.059 *$ & $-0.086 *$ & $0.030 * *$ & 0.116 & $-0.255^{*}$ & $0.328^{* *}$ & $-0.072 *$ & 0.026 & 1.000 & 0.082 & $-0.277 * *$ \\
\hline GDP & 0.056 & 0.048 & 0.054 & -0.027 & -0.002 & 0.081 & $0.125 *$ & -0.005 & -0.103 & -0.063 & $-0.006 *$ & 0.085* & 1.000 & 0.154 \\
\hline AAOIFI & -0.281 & 0.084 & 0.037 & -0.110 & -0.169 & -0.111 & $-0.451 * *$ & 0.200 & -0.420 & $0.073 * *$ & $-0.239 * *$ & $-0.319 * * *$ & -0.230 & 1.000 \\
\hline
\end{tabular}

The upper right half of the table shows Pearson's correlation coefficients while the lower left half of the table contains Spearman's rank-order correlations coefficients

*** Significant at $1 \%$ level, ** significant at $5 \%$ level, and *significant at $10 \%$ level. 
RD: risk disclosure, ROA: Net income/ total assets; LIST: 1 if the bank is listed in the stock exchange, 0 otherwise; BANKSIZE: Natural logarithm of total assets; BKAGE: Number of years; LEVERAGE: Long-term debt/ total assets; BlOCK: number of blokholders, HIGHEST_SH: highest shareholder ownership, GOV: government ownership; FOREIGN: Percent of shares owned by foreign shareholders; PSIA: Profit Sharing Investment Accounts; GDP: Natural logarithm of Gross domestic products; COUTRANSDEX: The index ranges from 0 to 10, with higher values indicating more disclosure.; AAOIFI: AAOIFI standards adoption 
Table 7: Determinants of risk disclosure using a GLS and GMM estimation

GLS estimation

GMM estimation

\begin{tabular}{|c|c|c|c|c|c|c|}
\hline & Coef & T-stat & P-value & Coef & T-stat & $\mathrm{P}$-value \\
\hline ROA & 164.79 & 0.36 & 0.72 & 253.84 & 1.01 & 0.312 \\
\hline LIST & -95.7 & -2.47 & $0.015 * *$ & -46.81 & 1.44 & 0.151 \\
\hline BANKSIZE & 10.387 & $1.98 * *$ & $0.05 * *$ & 20.533 & 5.23 & $0.000 * * *$ \\
\hline BKAGE & 3.38 & 3.34 & $0.001 * * *$ & 2.782 & 2.78 & $0.006 * * *$ \\
\hline LEVERAGE & -273.2 & -2.38 & $0.019 * *$ & -240.66 & $\mathbf{3 . 8 3}$ & $\mathbf{0 . 0 0 0} * * *$ \\
\hline COUTRANSDEX & 49.82 & 5.49 & $0.000 * * *$ & -25.53 & -2.64 & $0.01 * * *$ \\
\hline BLOCK & -61.11 & -5.64 & $0.000 * * * *$ & -46.878 & 3.70 & $0.00 * * *$ \\
\hline HIGHEST_SH & -46.87 & 2.63 & $0.001 * * *$ & -46.878 & 1.94 & $0.06^{*}$ \\
\hline FOREIGN & 305.229 & 7.34 & $0.000 * * *$ & -10.822 & 0.29 & 0.772 \\
\hline GOV & 10.56 & 0.53 & 0.89 & 24.098 & 0.46 & 0.648 \\
\hline PSIA & 4.19 & 3.55 & $0.001 * * *$ & 48.28 & 2.21 & $0.035 * *$ \\
\hline GDP & 92.5 & 3.55 & $0.001 * * *$ & -517.56 & -1.31 & 0.193 \\
\hline AAOIFI & 74.625 & 2.05 & $0.04 * * *$ & -42.89 & -1.30 & 0.197 \\
\hline \multicolumn{2}{|c|}{ Number of observation } & \multicolumn{2}{|r|}{432} & \multicolumn{3}{|c|}{432} \\
\hline
\end{tabular}




\begin{tabular}{lcc}
\hline Model & RE & \\
P value- Hausman Test & $0.000^{* * *}$ & $0.000^{* * * *}$ \\
R2 & 0.8931 & 0.8631
\end{tabular}

*** Significant at $1 \%$ level, ** significant at 5\% level, and *significant at $10 \%$ level.

RD: risk disclosure, ROA: Net income/ total assets; LIST: 1 if the bank is listed in the stock exchange, 0 otherwise; BANKSIZE: Natural logarithm of total assets; BKAGE: Number of years; LEVERAGE: Long-term debt/ total assets; BIOCK: number of blokholders, HIGHEST_SH: highest shareholder ownership, GOV: government ownership; FOREIGN: Percent of shares owned by foreign shareholders; PSIA: Profit Sharing Investment Accounts;; GDP: Natural logarithm of Gross domestic products; COUTRANSDEX: The index ranges from 0 to 10 , with higher values indicating more disclosure.; AAOIFI: AAOIFI standards adoption 
Table 8: Determinants of risk disclosure subcategories

\begin{tabular}{|c|c|c|c|c|c|c|c|c|}
\hline & D1 & D2 & D3 & D4 & D5 & D6 & D7 & D8 \\
\hline \multirow[t]{2}{*}{$\overline{\text { ROA }}$} & 5.42 & -79.47 & -19.32 & -32.04 & -9.005 & -3.146 & -9.82 & 4.74 \\
\hline & $(-0.28)$ & $(-0.64)$ & $(0.82)$ & $(0.49)$ & $(0.49)$ & $(0.52)$ & (1.62) & $(0.38)$ \\
\hline \multirow[t]{2}{*}{ LIST } & -1.86 & -8.416 & $-15.11 * * *$ & -9.98 & 0.944 & 0.125 & -7.206 & $3.87 * * *$ \\
\hline & $(0.73)$ & $(0.52)$ & $(4.92)$ & $(1.17)$ & $(0.40)$ & $(0.16)$ & $(0.92)$ & $(2.41)$ \\
\hline \multirow[t]{2}{*}{ BANKSIZE } & $0.66^{* * * *}$ & $9.36 * * *$ & 0.401 & $6.20 * * *$ & $0.512 *$ & -0.063 & $2.18 * *$ & 0.247 \\
\hline & (2.16) & $(4.79)$ & (1.08) & $(6.01)$ & (1.78) & $(0.66)$ & $(2.31)$ & $(1.27)$ \\
\hline \multirow[t]{2}{*}{ BKAGE } & $0.154 * *$ & $1.379 * * *$ & $0.484 * * *$ & $0.623 * * *$ & 0.013 & $0.118 * * *$ & 0.137 & 0.045 \\
\hline & (1.98) & $(2.77)$ & (5.11) & $(2.36)$ & $(0.19)$ & (4.89) & $(0.57)$ & $(0.91)$ \\
\hline \multirow[t]{2}{*}{ LEVERAGE } & $-12.085^{* * *}$ & $-14.43 * * *$ & 5.97 & $-7.422 * * *$ & 3.488 & 1.706 & $-5.524 * * *$ & 2.029 \\
\hline & $(2.46)$ & $(3.66)$ & (1.00) & $(4.51)$ & $(0.76)$ & $(1.12)$ & $(3.64)$ & $(0.65)$ \\
\hline \multirow[t]{2}{*}{ COUTRANSDEX } & $2.08 * * *$ & $12.92 * * *$ & $2.39 * * *$ & 0.501 & 0.678 & -0.091 & $1.131 * * *$ & 0.118 \\
\hline & (3.48) & $(3.20)$ & (3.13) & $(0.24)$ & (1.14) & $(0.46)$ & (5.77) & $(0.29)$ \\
\hline \multirow[t]{2}{*}{ BLOCK } & $-1.32 *$ & $-8.64 *$ & $-2.12 * * *$ & $-4.201 *$ & $-1.154 *$ & 0.309 & $-6.17 * * *$ & 0.528 \\
\hline & (1.73) & $(-1.78)$ & (2.39) & (1.76) & (1.61) & (1.31) & $(2.61)$ & (1.09) \\
\hline \multirow[t]{2}{*}{ HIGHEST_SH } & $-8.37 * *$ & 25.17 & $-13.52 * * *$ & 12.59 & -4.47 & 0.448 & 1.94 & -2.754 \\
\hline & (2.15) & $(1.02)$ & (2.87) & $(0.96)$ & $(1.22)$ & (1.27) & $(0.16)$ & (1.12) \\
\hline \multirow[t]{2}{*}{ FOREIGN } & 4.09 & -0.21 & $-10.72 * * *$ & 9.072 & $7.05 * * *$ & -1.091 & $-2.68 * * *$ & $6.416 * * *$ \\
\hline & $(1.40)$ & $(0.74)$ & (3.03) & $(0.92)$ & (2.58) & (1.21) & (2.97) & (3.47) \\
\hline \multirow[t]{2}{*}{ GOV } & -0.178 & 27.93 & $-14.98 * * *$ & 9.232 & 5.387 & $-2.73 * *$ & -1.05 & $10.53 * * *$ \\
\hline & $(0.04)$ & (1.06) & (3.00) & $(0.67)$ & (1.39) & (2.14) & $(0.83)$ & $(4.03)$ \\
\hline
\end{tabular}




\begin{tabular}{|c|c|c|c|c|c|c|c|c|}
\hline PSIA & $\begin{array}{c}0.162 * * \\
(2.17)\end{array}$ & $\begin{array}{r}22.24 * * \\
(1.97)\end{array}$ & $\begin{array}{l}1.207 \\
(0.56)\end{array}$ & $\begin{array}{c}1.61 \\
(1.27)\end{array}$ & $\begin{array}{c}8.102 * * * \\
(4.85)\end{array}$ & $\begin{array}{l}0.213 \\
(0.39)\end{array}$ & $\begin{array}{l}\text { 10.31* } \\
(1.87)\end{array}$ & $\begin{array}{l}-0.559 \\
(0.50)\end{array}$ \\
\hline GDP & $\begin{array}{c}--67.51 * * \\
(2.17)\end{array}$ & $\begin{array}{c}-25.43 * * \\
(-1.29)\end{array}$ & $\begin{array}{r}-390683 \\
(1.06)\end{array}$ & $\begin{array}{l}-8.123 \\
(0.78)\end{array}$ & $\begin{array}{r}-12.687 \\
(0.44)\end{array}$ & $\begin{array}{l}\mathbf{- 1 . 0 6} \\
(1.11)\end{array}$ & $\begin{array}{l}-5.47 \\
(0.57)\end{array}$ & $\begin{array}{l}-9.446 \\
(0.48)\end{array}$ \\
\hline AAOIFI & $\begin{array}{l}5.54 * * \\
(2.14)\end{array}$ & $\begin{array}{c}4.63 * * * \\
(2.83)\end{array}$ & $\begin{array}{l}1.966 \\
(0.63)\end{array}$ & $\begin{array}{l}1.66 * \\
(1.91)\end{array}$ & $\begin{array}{c}9.413 * * * \\
(3.87)\end{array}$ & $\begin{array}{l}0.745 \\
(0.93)\end{array}$ & $\begin{array}{l}1.49 * \\
(1.85)\end{array}$ & $\begin{array}{c}1.34 \\
(0.82)\end{array}$ \\
\hline
\end{tabular}

\begin{tabular}{lrrrrrrrr}
\hline Number of observations & 798 & 798 & 798 & 798 & 798 & 798 & 798 & 798 \\
\hline Adjusted R $^{2}$ & 0.6933 & 0.8338 & 0.4839 & 0.7933 & 0.6332 & 0.2045 & 0.7819 & 0.7428
\end{tabular}

$* * *$ Significant at $1 \%$ level, $* *$ significant at $5 \%$ level, and *significant at $10 \%$ level.

RD: risk disclosure, ROA: Net income/ total assets; LIST: 1 if the bank is listed in the stock exchange, 0 otherwise; BANKSIZE: Natural logarithm of total assets; BKAGE: Number of years; LEVERAGE: Long-term debt/ total assets; BIOCK: number of blokholders, HIGHEST_SH: highest shareholder ownership, GOV: government ownership; FOREIGN: Percent of shares owned by foreign shareholders; PSIA: Profit Sharing Investment Accounts; GDP: Natural logarithm of Gross domestic products; COUTRANSDEX: The index ranges from 0 to 10, with higher values indicating more disclosure.; AAOIFI: AAOIFI standards adoption 


\section{Risk disclosure index}

\begin{tabular}{|c|c|}
\hline & Capital structure and adequacy \\
\hline 1 & Capital structure \\
\hline 2 & Changes in capital structure \\
\hline 3 & Capital instruments \\
\hline 4 & Capital adequacy - tier $1 \& 2$ capital and ratios \\
\hline 5 & Equity Risk \\
\hline 6 & Contingency planning \\
\hline 7 & Capital management strategy \\
\hline 8 & Future capital plans \\
\hline & Financial risk \\
\hline 9 & Pricing Risk \\
\hline 10 & Liquidity \\
\hline 11 & Credit \\
\hline 12 & Changes in Interest Rates \\
\hline 13 & Credit Risk Exposure \\
\hline 14 & Insurance Risk \\
\hline 15 & Market Risk \\
\hline 16 & Interest Rate \\
\hline 17 & Exchange Rate \\
\hline \multirow[t]{2}{*}{18} & Sensitivity Analysis \\
\hline & Operational risk \\
\hline 19 & Operational risk management \\
\hline 20 & Operational value-at-risk (VaR/economic capital/Pillar 2 capital) \\
\hline
\end{tabular}




\begin{tabular}{|c|c|}
\hline 21 & Internal audit function/ \\
\hline 22 & Internal control system \\
\hline 23 & Business Disruption and Systems Failures \\
\hline 24 & Legal risks \\
\hline 25 & Compliance risk \\
\hline 26 & Fraud risk (internal/external) \\
\hline 27 & Damage to Physical Assets \\
\hline \multirow[t]{2}{*}{28} & Employment Practices and Workplace Safety \\
\hline & Financial instruments \\
\hline 29 & Derivatives \\
\hline 30 & Fair value \\
\hline 31 & Cumulative change in Fair value \\
\hline 32 & Hedging Description \\
\hline \multirow[t]{2}{*}{33} & Cash flow Hedge \\
\hline & Reserves \\
\hline 34 & Reserves \\
\hline 35 & Statutory Reserves \\
\hline \multirow[t]{2}{*}{36} & Legal Reserves \\
\hline & Segment Information \\
\hline 37 & Geographical Concentration \\
\hline \multirow[t]{2}{*}{38} & Customer Concentration \\
\hline & Accounting and presentation policies \\
\hline 39 & Risk Management \\
\hline 40 & Objective of Holding Derivatives \\
\hline 41 & Estimates \\
\hline
\end{tabular}




\begin{tabular}{|c|c|}
\hline 42 & Collateral Assets \\
\hline 43 & Financial Assets Impairment \\
\hline 44 & Assets Impairment \\
\hline 45 & Contingent Liabilities \\
\hline 46 & Contingent Assets \\
\hline 47 & Lower of Cost or Market \\
\hline \multirow[t]{2}{*}{48} & Contingency \\
\hline & General risks information \\
\hline 49 & Concentration of Credit Risk \\
\hline 50 & Customer Satisfaction \\
\hline 51 & High Competition \\
\hline 52 & Commodity \\
\hline 53 & Natural Disasters \\
\hline 54 & Communications \\
\hline 55 & Outsourcing \\
\hline 56 & Reputation \\
\hline 57 & Competition \\
\hline 58 & Weather Conditions \\
\hline \multirow[t]{2}{*}{59} & Change in Technology \\
\hline & Specific risks information for Islamic Banks \\
\hline 60 & Rate of return risk \\
\hline 61 & Shariah non-compliance risk \\
\hline 62 & Displaced commercial risk \\
\hline 63 & Equity investment risk \\
\hline 64 & Inventory risk \\
\hline
\end{tabular}




\begin{tabular}{|r|l|}
\hline 65 & Market risk \\
\hline 66 & Fiduciary risk \\
\hline & Specific Reserve for Islamic bank \\
\hline 68 & PER \\
\hline 69 & IRR \\
\hline
\end{tabular}

